\title{
Confinement of Concrete by Rope
}

\author{
Qudeer Hussain*, Kraisorn wongsopit \\ and Pichayut Jarusbumrungroj \\ Lecturer, Kasem Bundit University, \\ Thailand \\ qudeer.hus@kbu.ac.th
}

\author{
Sharukh Shoaib \\ Graduate student, Kasetsart University, \\ Thailand
}

\author{
Panuwat Joyklad \\ Lecturer, Srinakharinwirot University, \\ Thailand
}

\begin{abstract}
This study presents results of an experimental investigation conducted to investigate the axial behavior of natural rope confined concrete. Natural ropes such as coir, coconut and hemp ropes are easily available both in developing and developed counties. In this study, small scale concrete columns were confined using natural rope made of hemp fibers. The hemp rope was applied in three different thicknesses i.e. one layer, two layers and three layers. Both confined and un-confined concrete columns were tested under monotonic axial compression. The results indicate that rope confinement is very effective method to enhance ultimate strength and strain of confined concrete. The confinement level has a significant effect on strength and ductility of rope confined concrete. There is found significant increase in strength and ductility of concrete with an increase in the confinement level.
\end{abstract} strain

Keywords-concrete, column, confinement, rope, strength and

\section{INTRODUCTION}

The need for strengthening (or stiffening of) reinforced concrete (RC) and pre-stressed concrete (PC) structures is becoming more apparent, particularly when there is an increase in load requirements, a change in use, a degradation problem, or some design/construction defects [1]. Potential solutions range from replacement of the structure to strengthening with a variety of techniques [1]. There existed a large number of previous researches on the use of concrete and steel by means of external jacketing for retrofitting and strengthening the deficient concrete members $[2,3]$. However, the use of such materials has posed some disadvantages such as intensive labour demands and increase in weight and volume. Steel jacketing also involves corrosion problems and difficulty in handling heavy steel plates [4]. The use of FRP materials for structural repair presents several advantages and had been recently investigated all over the world [5]. The main advantages of FRP materials are related to their light weight, high strength and stiffness, resistance to corrosion, flexibility, and rapidity of application [6]. The main disadvantages are related to their high material cost and availability. Sprayed Fiber Reinforced Polymers SFRP has been successfully studied for strengthening and rehabilitation of concrete members. The salient advantages of SFRP technique are easy fast application. However the necessary equipment for sprayed fibers is very expansive and is not easily available [7-9].
In contrast to the traditional strengthening techniques, recently a new method of strengthening or retrofitting "Rope Jacketing" has been developed by some researchers. The ropes are easily available all around the world with nominal diameter and strength properties. The rope jacketing is easy to install since it does not require skill labor and specific equipment. At present different kinds of ropes are manufactured in the industries such as steel wire ropes, polypropylene, nylon and other fibrous materials such as silk, wool and natural fibers. Rousakis (2012) studied a noval confining technique using fiber ropes as external strengthening reinforcement. The ropes are mechanically anchored through steel collars, avoiding the use of impregnating resins. The fiber ropes are made of vinylon or polypropylene, having different modulus of elasticity and deformation at failure. Confining of concrete through fiber ropes leads to substantial upgrade of concrete strain at failure reaching values of $13 \%$ strain, while its strength is also greatly enhanced [10]. Shabana et al. 2015 performed an experimental investigation to study the effect of coir rope wrapping on the compressive strength of short axially loaded concrete members. The tests were carried out with ropes of different diameters $0.6 \mathrm{~cm}, 1 \mathrm{~cm}$ and $1.4 \mathrm{~cm}$ at spacing of $0.0 \mathrm{~h}, 0.1 \mathrm{~h}, 0.2 \mathrm{~h}$ and $0.3 \mathrm{~h}$, where $\mathrm{h}$ is the height of the specimen. Maximum improvement was obtained for wrapping with coir rope of diameter $1.4 \mathrm{~cm}$ at $0.0 \mathrm{~h}$ spacing. The strength was found to be increased with increase in diameter of rope and decreased with increase in spacing [11]. The objective of this study is to investigate the axial response of natural fiber rope such as hemp rope confined concrete. To achieve this goal an experimental program is conducted. A total of 8 small scale concrete columns were tested under monotonic axial compression. The hemp rope was wrapped on concrete columns in three different layers i.e., one layer, two layers and three layers.

\section{EXPERIMENTAL PROGRAM}

\section{A. Specimen Details}

In this experimental program, small scale concrete columns were constructed and tested to investigate the axial response of hemp fiber rope confined concrete. The nominal dimensions of concrete columns are shown in the Fig. 1. 

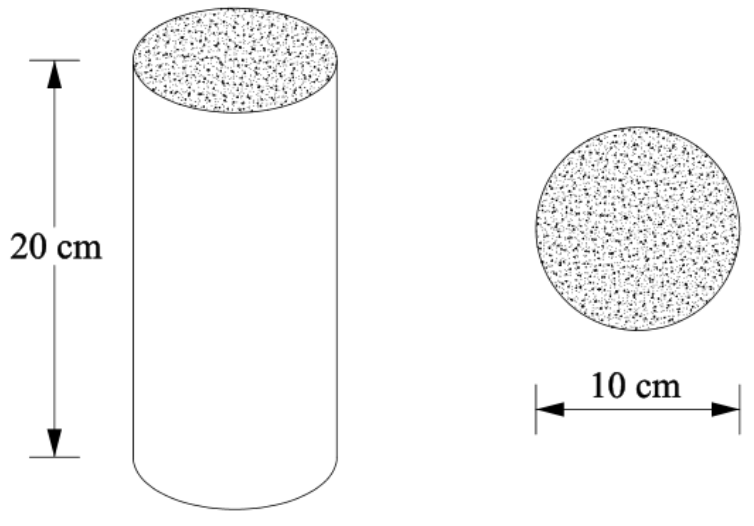

Fig. 1. Details of test specimen.

\section{B. Test Matrix}

In this experimental program a total of eight concrete columns were tested to investigate the axial response of hemp fiber rope confined concrete. Two concrete columns were tested without rope confinement as control specimens and remaining six concrete columns were wrapped with hemp rope. Hemp rope confinement was provided in three layers i.e., one layer, two layers and three layers. The details of experimental program are summarized in Table I.

TABLE I. DETAILS OF TEST MATRIX.

\begin{tabular}{|l|l|l|}
\hline Specimen & Ropes layers & No. of specimen \\
\hline CON & - & 2 \\
\hline R-1 & One & 2 \\
\hline R-2 & Two & 2 \\
\hline R-3 & Three & 2 \\
\hline
\end{tabular}

\section{Rope Strengthening Process}

In this study, the natural hemp fiber ropes were used to strengthen the concrete columns. Natural hemp rope was obtained from local manufacturers. The nominal diameter of hemp fiber rope was $3 \mathrm{~mm}$. The rope was wrapped to the concrete columns by hand wrap up technique as shown in the Fig. 2 and 3. The hemp rope was wrapped to the specimens in three layers i.e., one, two and three layers.

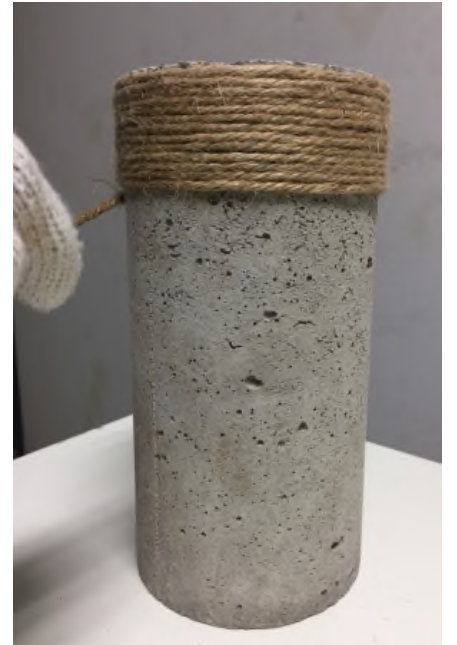

Fig. 2. Hemp rope wrapping process.

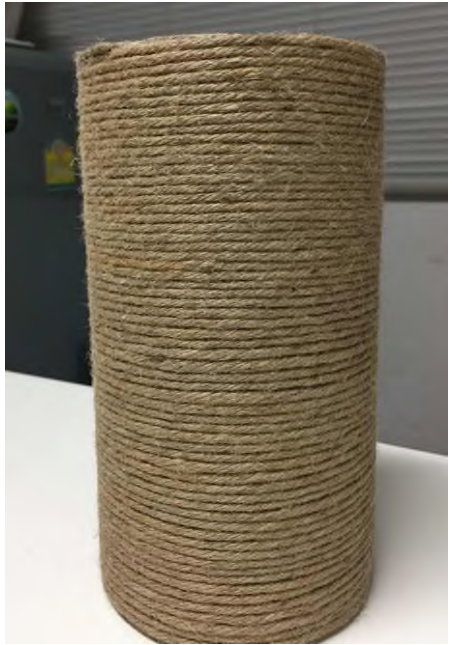

Fig. 3. A typical rope strengthen concrete specimen.

\section{Test Setup}

All concrete columns were tested under uni-axial monotonic axial compression up to failure in a Universal Testing Machine (TUM) of $1000 \mathrm{kN}$ capacity. The load was applied at a constant rate of $0.5 \mathrm{~mm} /$ minute and data were recorded at the time interval of 3 seconds by an electronic data logger. Prior to the testing the columns ends were additionally wrapped with glass fiber roving to avoid premature failure of the columns at the ends.

\section{E. Material Properties}

In this study a single batch of concrete (28 day's target strength was $15 \mathrm{MPa}$ ) was used to cost the concrete specimens. The mix components are shown in the table. Type-1 Portland cement was used to prepare concrete. The nominal size of coarse aggregates was $19 \mathrm{~mm}$. The hemp fiber ropes were obtained from the local supplier. The nominal diameter of hemp fiber rope was $3 \mathrm{~mm}$.

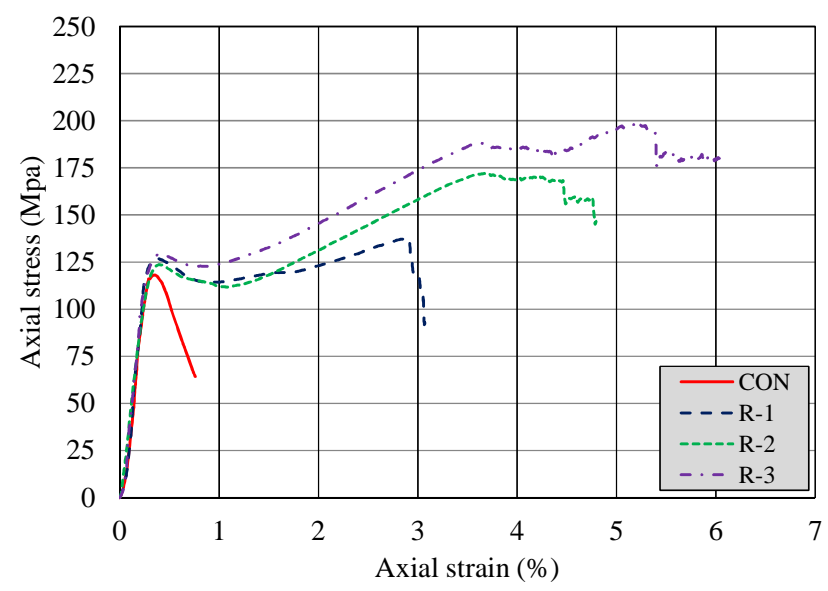

Fig. 4. Axial stress versus strain responses. 


\section{TEST RESULTS AND DISCUSSION}

\section{A. Overall Behavior and Stress-Strain Response}

The axial stress versus strain responses of control and hemp rope confined columns are shown in the Fig. 4. As can been seen that irrespective of confinement level, the typical stress strain response of hemp rope confined concrete is tri-linear (composed of three parts). The first part of the curve is described by a linear line similar to the curve of the unconfined concrete. Second part is descending part where axial stress decreases with an increase in the axial strain. In the third part, the axial stress versus strain curves of confined concrete increase linearly again until a sudden failure occurs due to the rupture of the hemp fiber rope.

TABLE II. EXPERIMENTAL TEST RESULTS

\begin{tabular}{|c|c|c|c|c|}
\hline Specimen & $\begin{array}{c}\text { Ultimate } \\
\text { stress } \\
\text { (MPa) }\end{array}$ & $\begin{array}{c}\text { \% Increase } \\
\text { in ultimate } \\
\text { stress }\end{array}$ & $\begin{array}{c}\text { Ultimate } \\
\text { strain (\%) }\end{array}$ & $\begin{array}{c}\text { \% Increase } \\
\text { in ultimate } \\
\text { strain }\end{array}$ \\
\hline CON & 15.03 & - & 0.31 & - \\
\hline R-1 & 17.49 & 16.00 & 2.85 & 714.0 \\
\hline R-2 & 21.93 & 46.00 & 3.69 & 954.0 \\
\hline R-3 & 25.03 & 67.00 & 5.76 & 1545.0 \\
\hline
\end{tabular}

\section{B. Effect of Rope Thickness}

The experimental results indicate that confinement level has a significant effect on the ultimate load carrying capacity and strain of confined concrete. There is found increase in ultimate load carrying capacity and ultimate strain of hemp rope confined concrete with an increase in the confinement level. The concrete column R-1 (One layer of hemp rope) failed at 16\% and 714\% higher compressive strength and axial strain, respectively, compared to the control column. When the thickness of rope was increased to 2 layers as in the column R-2, the compressive strength and strain were increased by $46 \%$ and 954 , respectively. The highest increase in compressive strength and strain was $67 \%$ and $1545 \%$, respectively, recorded for the column R-3 with three layers of hemp fiber rope.

\section{Failure Modes}

The control columns (concrete columns without rope confinement) were failed in typical compression manner. All hemp fiber rope confined columns were essentially failed due to the rupture of hemp rope as shown in the Figs. 5-7. The rupture of hemp fiber rope was observed at the middle of concrete columns with a drop in the load carrying capacity.

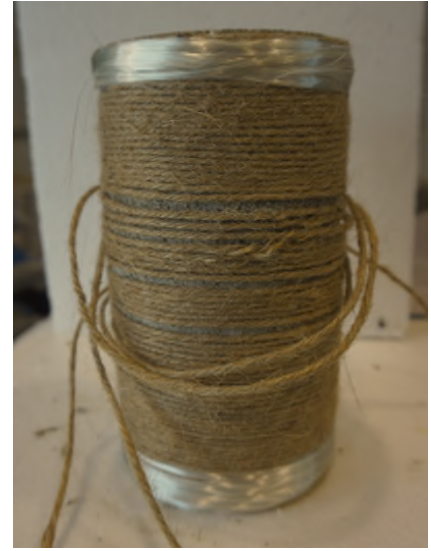

Fig. 5. Typical failure mode of R-1 specimen.

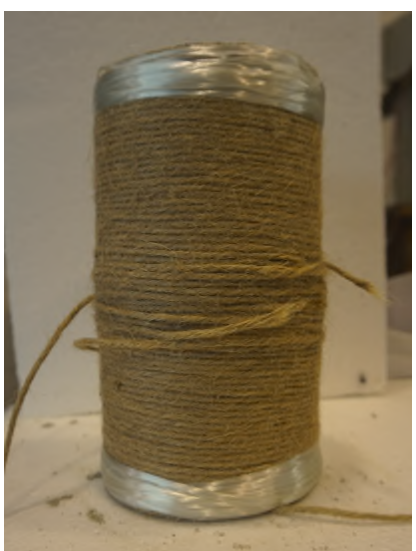

Fig. 6. Typical failure mode of R-2 specimen.

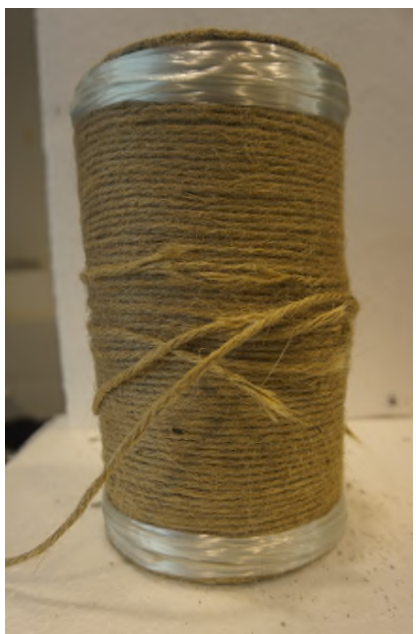

Fig. 7. Typical failure mode of R-3 specimen.

\section{CONCLUSIONS}

This study presents results of an experimental investigation conducted to investigate the axial behavior of natural rope confined concrete. Based on experimental results following conclusions can be drawn; 1) Natural fiber rope confinement is an effective method to enhance strength and deformability of concrete columns, 2) The increase in the compressive strength and deformability varies with the hemp fiber rope thickness. 


\section{REFERENCES}

[1] M. Arduini and A. Nanni, "Behavior of precracked RC beams strengthened with carbon FRP sheets". J. Comp. Constr. vol. 1, no. 2, pp. 63-70, 1997.

[2] Y. Chai, M. Priestley and F. Seible. "Analytical model for steel jacketed RC circular bridge columns”. J. Struct. Eng. vol. 120, pp. 2358-2376, 1994.

[3] M. Rodriguez and R. Park. "Seismic load tests on reinforced concrete columns strengthened by jacketing”. ACI Struct. J. vol. 91, pp. 150-159, 1994.

[4] M. Engindeniz, L.F. Kahn and A.H. Zureick. "Repair and strengthening of reinforced concrete beam-column joints: State of the art". ACI Struct. J. vol. 102, pp. 187-197, 2005.

[5] O. Chaallal, M.J. Nollet and D. Perraton. "Strengthening of reinforced concrete beams with externally bonded fiber-reinforced-plastic plates: Design guidelines for shear and flexure". Canadian J. Civil Eng. vol. 25, pp. 692-704, 1998.

[6] M. Arduini and A. Nanni, "Behavior of precracked RC beams strengthened with carbon FRP sheets". J. Comp. Constr. vol. 1, no. 2, pp. 63-70, 1997.

[7] E. Shaheen and N.G. Shrive. "Sprayed glass fibre reinforced polymer masonry columns under concentric and eccentric loading". Canadian J. Civil Eng. vol. 34, pp. 1495-1505, 2007.

[8] S.M. Soleimani and N. Banthia. "Shear strengthening of RC beams using sprayed glass fiber reinforced polymer". Adv. Civil Eng. vol. 2012, pp. 120, 2012.

[9] A.J. Boyd, N. Liang, P.S. Green and K. Lammert. "Sprayed FRP repair of simulated impact in prestressed concrete girders". Constr. Build. Mater. vol. 22, pp. 411-416, 2008.

[10] T.C. Rousakis, Confinement of concrete columns by fiber rope reinforcements. In J. Monti ed., The 6th International Conference on FRP Composites in Civil Engineering-CICE, 2012, pp. 13-15.

[11] M.M. Athira, S.S. Lalna, C. Prasun, K.K. Rafeekha, K.R. Rajimol and A. M. Safna, Effect of Coir Rope Wrapping on the Compressive Strength of Short Axially Loaded Concrete Members, International Journal of Research in Advent Technology, pp. E-ISSN: 2321-9637 Special Issue International Conference on Technological Advancements in Structures and Construction “TASC- 15", 10-11 June 2015. 2015, pp. 20-25. 